\title{
Bedding preferences of pregnant laboratory-reared mice
}

\author{
J. B. MULDER \\ Michigan State University, East Lansing, Michigan 48824
}

\begin{abstract}
Pregnant ARS Ha (ICR) Swiss mice were allowed to select from 10 commercially available bedding products for parturition and rearing young. Combinations of bedding materials were most often selected. Products of wood origin were overwhelmingly preferred. Rates for the selection of bedding materials from the 20 tests were Aspen Bed 100\%, Cedar Shavings 75\%, Pinewood Shavings 45\%, Ab-Sorb-Dri 5\%, and Stop "O" $5 \%$.
\end{abstract}

The purpose of this study was to determine if pregnant Swiss mice preferred a specific bedding material for parturition and rearing young.

\section{METHOD}

Bedding test units, with 12 individual chambers, were constructed from poster board coated with fiberglass. A standard top from a small rodent cage was suspended in the center area to provide water and food. Hardware cloth with $.64-\mathrm{cm}$ mesh was placed on top of the chamber and held in place with lead weights. Each individual chamber had a floor area of $40 \mathrm{~cm}^{2}$. A round passage $1.3 \mathrm{~cm}$ above the unit floor $6 \mathrm{~cm}$ in diam connected each chamber with the open center area. The walls of the test unit were $20 \mathrm{~cm}$ high. Other dimensions of the unit are presented in Figure 1.

Ten different commercial bedding products were donated for testing (Table 1). A $10-\mathrm{cm}^{3}$ volume of each bedding material was placed randomly into different chambers with two chambers and the center area remaining free from bedding.

Twenty female ARS Ha (ICR) Swiss mice were raised and bred in opaque rodent cages. Shredded newspaper, sterilized with ethylene oxide, was used for bedding. Individual pregnant mice were placed in the bedding test unit 3 to 5 days prior to parturition. Purina rodent chow and water were provided ad lib. Room temperature was maintained at $72^{\circ} \mathrm{F}$ with a relative humidity of $40 \%-60 \%$. The test units were maintained in an isolated building with limited access.

Each mouse was allowed to select the bedding preferred for parturition and rearing of her young. Newborn young werc counted the first day following birth. The mother and litter were then left undisturbed for 1 week. At 1 week of age, the young were counted and placed into a small standard opaque rodent cage with their mother. The cage was bedded with the same material selected originally. At 3 weeks of age the young were again counted and the test terminated. The bedding units were sanitized after each test. Twenty consecutive tests were conducted.

\section{RESULTS}

The bedding selected and number of young born and surviving at 1 and 3 weeks of age are presented in Table 2. Most of the females selected a mixture of bedding materials. Fairly equal volumens of the different

Requests for reprints should be sent to J. B. Mulder, $127 \mathrm{D}$ Giltner Hall, Michigan State University, East Lansing, Michigan 48824 . products were mixed. Nests were all built in the chambers of the test units; never in the center area. With the exception of Stop " 0 " in Test 7 , all bedding selections were products of wood origin. Bedding preference percentages from the 20 tests were Aspen Bed $100 \%$, Cedar Shavings $75 \%$, Pinewood Shavings 45\%, Ab-Sorb-Dri 5\%, and Stop "0" 5\% (Table 3). Survival of young was not greatly influenced by the bedding materials selected except in Test 7 where nearly $50 \%$ did not survive the first week.

\section{DISCUSSION}

Arrington (1972) presents 11 desirable properties for

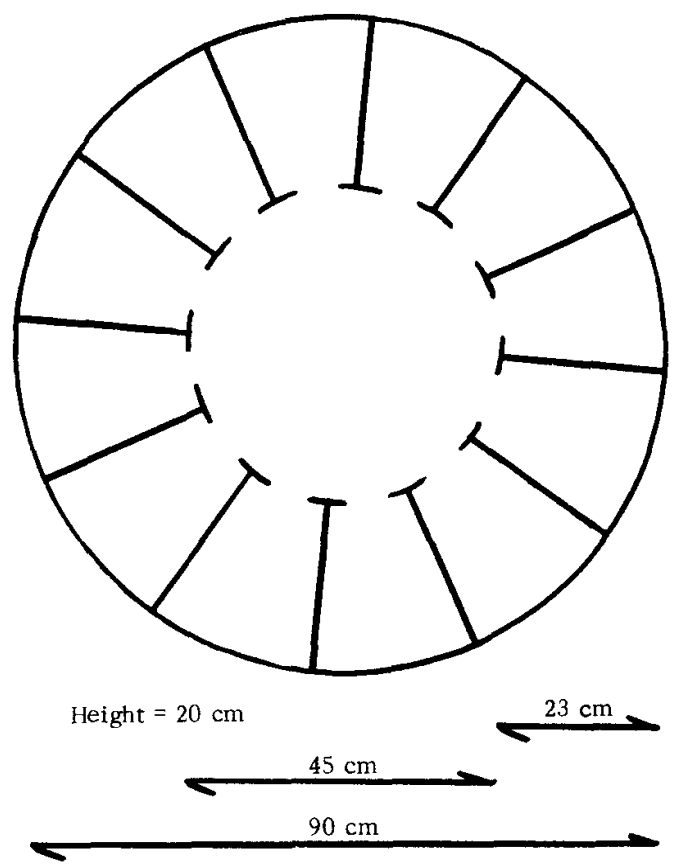

Figure 1. Dimensions of the bedding test unit. 
Table 1

Bedding Materials Tested

\begin{tabular}{|c|c|c|}
\hline Name & $\begin{array}{l}\text { Product } \\
\text { Base }\end{array}$ & Supplier \\
\hline Ab-Sorb-Dri & Wood & $\begin{array}{l}\text { Lab Products } \\
\text { Garfield, NJ }\end{array}$ \\
\hline Aspen Bed & Wood & $\begin{array}{l}\text { American Excelsior Co. } \\
\text { Edina, MN }\end{array}$ \\
\hline Cedar Shavings & Wood & $\begin{array}{l}\text { Osage Products } \\
\text { Eldon, MO }\end{array}$ \\
\hline Clean and Dry & $\begin{array}{l}\text { Bentonite } \\
\text { Clay }\end{array}$ & $\begin{array}{l}\text { Bratton Enterprises, Inc. } \\
\text { Oran, MO }\end{array}$ \\
\hline Lab Litter & Wood & $\begin{array}{l}\text { The Willis Co. } \\
\text { Jackson, NB }\end{array}$ \\
\hline Litter Green & Alfalfa & $\begin{array}{l}\text { The McFadden Co. } \\
\text { Overland Park, KS }\end{array}$ \\
\hline San-I-Cel & Corn Cob & $\begin{array}{l}\text { Paxton Processing Co. } \\
\text { Paxton, IL }\end{array}$ \\
\hline Stop "O" & Corn Cob & $\begin{array}{l}\text { C. P. Hall } \\
\text { Chicago, IL }\end{array}$ \\
\hline Super San-I-Cel & Corn Cob & $\begin{array}{l}\text { Paxton Processing Co. } \\
\text { Paxton, IL }\end{array}$ \\
\hline Pinewood Shavings & Wood & $\begin{array}{l}\text { Smithton Industries } \\
\text { Smithton, MO }\end{array}$ \\
\hline
\end{tabular}

laboratory animal bedding: absorbancy, freedom from dust, freedom from objectionable odors, nonedible or nonnutritive, inexpensive, nontoxic, freedom from insects and vermin, easy removal and disposal, ability to neutralize odors, capability of sterilization, and nonfermentable. Robie and Walburg (1969), using ground corncobs or pinewood shavings sterilized with

Table 2

Bedding Selection by Pregnant ARS Ha (ICR) Swiss Albino Mice and Survival of Young

\begin{tabular}{|c|c|c|c|c|}
\hline \multirow{3}{*}{$\begin{array}{c}\text { Test } \\
\text { Number }\end{array}$} & \multirow{3}{*}{$\begin{array}{l}\text { Bedding } \\
\text { Selected }\end{array}$} & \multicolumn{3}{|c|}{$\begin{array}{l}\text { Young } \\
\text { Surviving }\end{array}$} \\
\hline & & Young & 1 & 3 \\
\hline & & Born & Week & Weeks \\
\hline 1 & Aspen, Cedar & 9 & 9 & 9 \\
\hline 2 & Aspen, Cedar & 10 & 10 & 10 \\
\hline 3 & Aspen, Cedar & 13 & 12 & 12 \\
\hline 4 & $\begin{array}{l}\text { Ab-Sorb-Dri, Aspen, } \\
\text { Cedar, Pinewood }\end{array}$ & 10 & 10 & 10 \\
\hline 5 & Aspen, Cedar, Pinewood & 8 & 7 & 6 \\
\hline 6 & Aspen, Cedar, Pinewood & 7 & 5 & 5 \\
\hline 7 & Aspen, Cedar, Stop "O" & 11 & 6 & 6 \\
\hline 8 & Aspen, Cedar, Pinewood & 3 & 3 & 3 \\
\hline 9 & Aspen & 5 & 5 & 5 \\
\hline 10 & Aspen & 12 & 12 & 11 \\
\hline 11 & Aspen, Cedar & 6 & 6 & 6 \\
\hline 12 & Aspen & 11 & 11 & 10 \\
\hline 13 & Aspen, Pinewood & 11 & 11 & 11 \\
\hline 14 & Aspen, Pinewood & 12 & 12 & 12 \\
\hline 15 & Aspen, Cedar, Pinewood & 9 & 9 & 9 \\
\hline 16 & Aspen, Cedar, Pinewood & 10 & 10 & 10 \\
\hline 17 & Aspen, Cedar & 9 & 9 & 9 \\
\hline 18 & Aspen, Cedar & 12 & 9 & 9 \\
\hline 19 & Aspen, Cedar, Pinewood & 10 & 10 & 10 \\
\hline 20 & Aspen, Cedar & 12 & 12 & 12 \\
\hline
\end{tabular}

Table 3

Percent Selection of Bedding Materials by Pregnant ARS Ha (ICR) Swiss Albino Mice

\begin{tabular}{lc}
\hline Bedding & $\begin{array}{c}\text { Percent Selection } \\
\text { in 20 Tests }\end{array}$ \\
\hline Aspen & 100 \\
Cedar & 75 \\
Pinewood & 45 \\
Ab-Sorb-Dri & 5 \\
Stop "O" & 5 \\
\hline
\end{tabular}

ethylene oxide or steam, determined that the bedding did not produce a significant difference in the number of mice born or weaned. They concluded that material selected for bedding should be determined by factors such as availability, cost, and efficiency of operation.

Bedding utilized for mice has generally been selected for economic reasons rather than on an animal preference basis. When allowed free selection, physical comfort may be a determining factor. The wood origin products may have been selected for comfort; however, it is conceivable that these products did not provide better survival or growth rates than some of the materials not selected. The conclusion, therefore, is simply that pregnant ARS Ha (ICR) Swiss mice preferred bedding materials of wood origin when allowed a choice and infant survival was adequate with these materials. Similar results were reported when pregnant rats were given a choice of bedding materials (Mulder, 1974b). Groups of virgin female mice also selected wood origin products when housed over a long-term period (Mulder, 1974a).

Obviously, many factors must be considered in selecting bedding for mice. Assuming that wood origin materials provide more comfort and that comfortable mice are more normal subjects, possibly the use of these bedding materials has merit.

The desire for a larger volurne of bedding may have resulted in mixing materials. However, Tests 9,10 , and 12 refute this argument since one measure of bedding was adequate for these animals. Generally the chamber with Aspen Bed was selected as home base and other materials added. The high death loss of young in Test 7 may have been caused by a maternal defect or other unknown factors.

Several observations were made from this study: (1) mice will select bedding materials if given an opportunity, (2) wood origin materials are overwhelmingly preferred, and (3) after many years of laboratory confinement, mice still prefer bedding materials which are common in their original native habitat.

\section{REFERENCES}

Arrington, L. R. Housing and caging. In Introductory laboratory animal science. Danville, Illinois, Interstate Printers and Publishers, 1972.

Mulder, J. B. Bedding preferences of mice over long-term confinement. Laboratory Animal Digest, 1974a, 9, 54-56.

Mulder, $J$. B. Bedding selection by rats. Laboratory Animal Digest, 1974b, 9, 27-30.

Robie, D. M., \& Walburg, H. E. Influence of bedding on mouse reproductivity and infant mortality. Abstract, American Association of Laboratory Animal Science Session, 1969.

(Received for publication November 11, 1974, revision received December 10,1974 .) 